\title{
Canada instrumental in watering down elements of noncommunicable diseases plan
}

A s negotiators worked to finalize some manner of formal action plan for debate and ratification at the United Nations summit on noncommunicable diseases (NCDs), Canada appears to have been a major player in watering down some of its provisions.

Critics say that Canada was instrumental in pressing for the exclusion of a pledge to support universal health care, in removing a passage that would have limited the impact that food and alcohol corporations have on public health policies, and in not addressing trade-related barriers to global health.

Documents obtained by CMAJ indicate that Canada has been active in dampening aspects of the plan to tackle a global scourge of noncommunicable diseases associated with as many as 36 million deaths annually $-80 \%$ of them in developing nations.

The plan was scheduled to be ratified at the summit in New York City, New York, from Sept. 19-20. The Draft Political Declaration of the High-level Meeting on the prevention and control of non-communicable diseases (www .who.int/nmh/events/un_ncd_summit 2011/political_declaration.pdf), dated Sept. 9, is supported by Canada, officials from the Public Health Agency of Canada confirmed during a telebriefing to more than two dozen representatives of national health groups on Sept. 14.

But that triggered considerable criticism from telebriefing participants, who feel Canada at times played an obstructionist role in crafting the noncommunicable diseases action plan.

Canadian negotiators appear to have been among those who sought to block efforts to include a pledge in support of universal health care systems that was contained within an earlier draft, says Bill Jeffery, national coordinator of the Ottawa, Ontariobased Centre for Science in the Public Interest. "There was no indication of

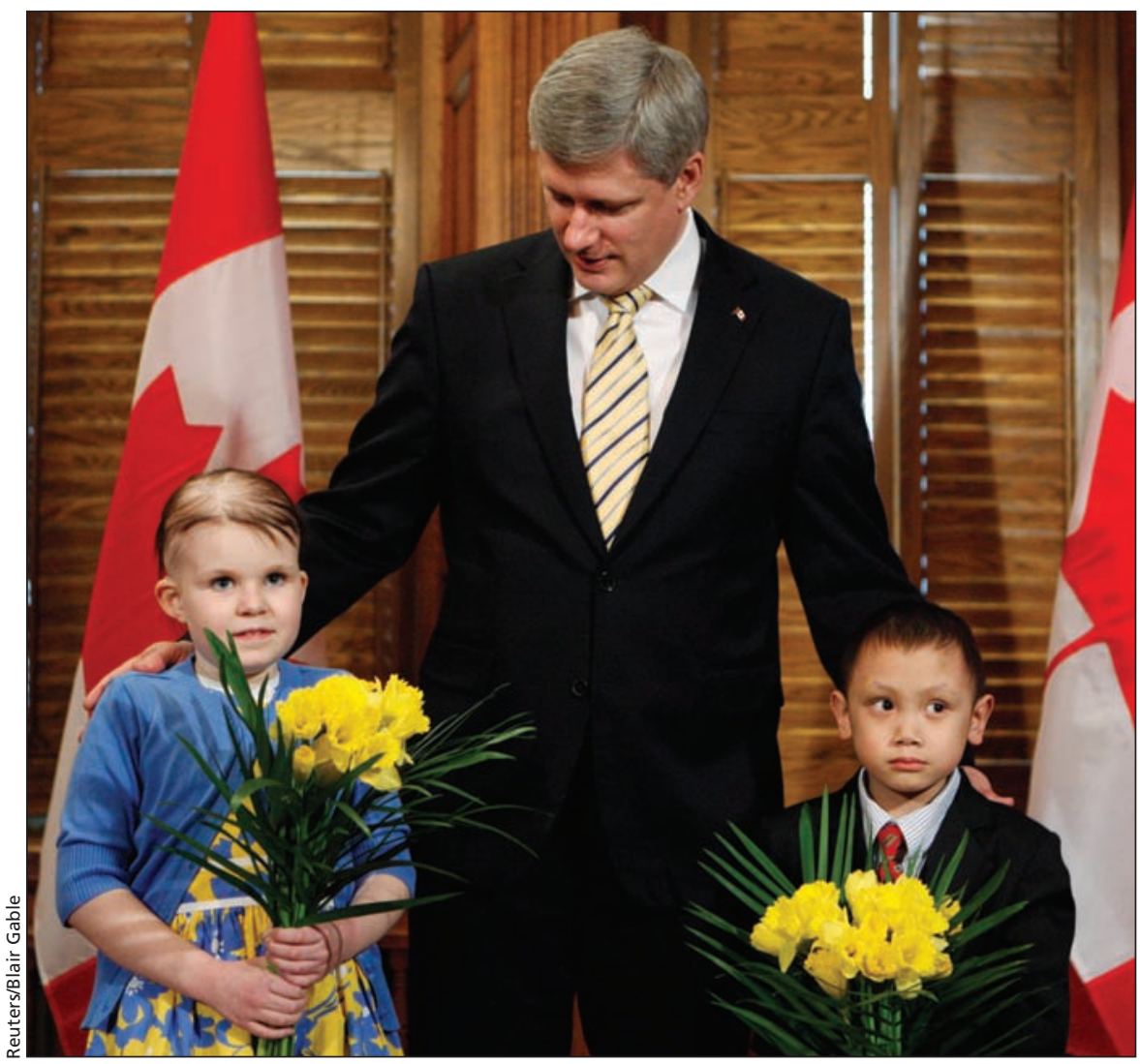

Although Canadian Prime Minister Stephen Harper received daffodils to mark the Canadian Cancer Society's annual daffodil month, Canada is accused of being obstructionist in the development of a noncommunicable diseases action plan.

opposition from anyone else to these efforts" Jeffery says.

"Some of the big donor nations, Canada and others, were saying that there should not be additional burdens on [foreign aid budgets]. When people started talking about universal access, there were countries, likely including Canada, that pushed back," says Ann Keeling, chair of The NCD Alliance and chief executive officer of the International Diabetes Federation.

The draft declaration includes recognition for "the importance of universal coverage in national health systems, especially through primary health care and social protection mechanisms, including sustainable health financing structures to provide access to health care services for all, in particular, for the poorest segments of the population.'

Jeffery says PHAC officials, during the telebriefing, refused to address his inquiries on Canada's efforts to retract the passage and instead, called for questions from other participants.

Jeffery says Canadian officials were also instrumental in the removal of a passage that would have acknowledged that food and alcohol corporations, much in the manner of tobacco companies, may have inherent conflicts of interest in advising on public health policies.

"It seemed that in one of the most recent versions of the draft Canada offered some text on that," Jeffery says. "But that conflict of interest text was 
removed almost immediately. It was in there in one version and now it's out, and Canada supported it."

Jeffery, again, pressed PHAC officials on the issue and they did not dispute the assertion that Canada opposed the notion, saying that they see private sector engagement as "part of the solution" and that while "there are some areas we are happier with than others, on balance, we [are] not unhappy."

Again, documents obtained by $C M A J$ support the proposition that Canada successfully pushed to retract a passage about conflict of interest.

The draft declaration sought and supported by Canada adopts an alarmingly passive approach "that has no punch to it," says Ronald Labonté, Canada Research Chair in Globalization and Health Equity at the University of Ottawa.

While many hoped that the summit would result in the creation of a regulatory regime to reduce trade in tobacco, alcohol and unhealthy foods, the draft declaration "seems to [be] trying to avoid identifying what we already know for a certainty are the causes of this global pandemic," Labonté says.

Reforming food export policies to promote global health will ultimately be an essential component of any effort to contain NCDs, says Dr. Salim Yusuf, professor of medicine at McMaster University in Hamilton, Ontario, and principal investigator on an ongoing 17-nation study of risk factors for chronic disease among 400000 patients.

When Labonté pressed PHAC officials to explain why the draft makes no mention of international mechanisms to constrain trade in substances presenting health risks, PHAC officials declined comment. Nor did they respond to $C M A J$ requests for an interview.

Jeffery says Canada has moved in the right direction on several issues but frets that commercial concerns are trumping public health. So too does the International Association of Consumer Food Organizations, noting in a letter to Dr. Joseph Deiss, president of the UN General Assembly, that "food compa- nies' persistence in using any lawful food marketing practices regardless of the net effect on public health have created a food marketing environment that favours product sales at the expense of nutrition status and population health" (http://cspinet.org/canada/pdf/final.iacfo -un-summit.nutritionadvice.pdf).

Canada, Keeling says, "pushed back" when it came to trade-related issues throughout the negotiations.

Although the draft declaration will commit signatories to "work toward reducing the use of salt in the food industry in order to lower sodium consumption," Canada has been criticized by World Action on Salt and Health, a nonprofit advocacy group, for working with the European Union, Australia, Japan and the United States to block a Norwegian effort to include a salt consumption target of five grams a day within the declaration. Paul Christopher Webster, Toronto, Ont.

CMAJ 2011. DOI:10.1503/cmaj.109-4008 